\title{
OBRAZ CHRZEŚCIJAŃSKIEGO WŁADCY W LISTACH ŚW. AMBROŻEGO
}

Gdy w roku 374, Aureliusz Ambroży, namiestnik prowincji Emilii-Ligurii, został wybrany biskupem Mediolanu, od ponad 60 lat religia chrześcijańska miała status religio licita. Po ponad 300 latach od wydarzeń Pięćdziesiątnicy sytuacja chrześcijan uległa zmianie - mogli bez przeszkód wyznawać swoją wiarę, budować kościoły, a biskupi stali się osobami publicznymi, z których zdaniem liczono się, a nie wysyłano na wygnanie i karano śmiercią. W kilka lat później, jeszcze za życia Ambrożego, chrześcijaństwo otrzymało od cesarza Teodozjusza status religio regalis, co jeszcze bardziej wzmocniło pozycję chrześcijan. W takich okolicznościach posługę biskupią w mieście-rezydencji cesarza pełnił Ambroży. Zarówno jako zarządca prowincji, jak i jako biskup Mediolanu, Ambroży miał częste okazje do kontaktów z imperatorami ${ }^{1}$. Jako chrześcijanin i jako biskup miał z pewnością obraz doskonałego władcy, który - w zmienionych już okolicznościach społecznych i politycznych - miał być władcą chrześcijańskim. Ambroży zaś jako pierwszy tej rangi biskup, uznany za Ojca i Doktora Kościoła, jest świadkiem szczególnym tej przemiany i patrzenia na cesarza jako władcę chrześcijańskiego i współwyznawcę, a nie wroga i prześladowcę. Ponadto po tzw. Edykcie Mediolańskim stało się koniecznym określenie wzajemnych relacji pomiędzy Kościołem a państwem. Należało ustalić, jak dalece cesarz może ingerować w sprawy Kościoła i jakie prawa i obowiązki ma biskup wobec cesarza. Ogromne znaczenie miała w tym względzie postawa biskupa Mediolanu Ambrożego². Warto zatem zwrócić uwagę na postać Ambrożego i jego - wyjątkową wśród zachowanych źródeł - korespondencję $\mathrm{z}$ panującymi za jego pontyfikatu cesarzami i na to jak postrzegał chrześcijańskich imperatorów i jaki według niego powinien być chrześcijański władca ${ }^{3}$.

* Ks. dr Marcin Wysocki - adiunkt w Katedrze Patrologii Greckiej w Instytucie Historii Kościoła i Patrologii na Wydziale Teologii Katolickiego Uniwersytetu Lubelskiego Jana Pawła II; e-mail: mwysocki@kul.lublin.pl.

${ }^{1}$ O szczególnej roli biskupa Ambrożego zob. R. Andrzejewski, Między Bogiem a cesarzem Ambroży z Mediolanu, AK 93 (1979) 64-72.

${ }^{2}$ Por. J. Pałucki, Święty Ambroży jako duszpasterz w świetle ekshortacji pastoralnych, Lublin 1996, 65.

${ }^{3}$ Por. K. Gross-Albenhausen, ,, Imperator christianissimus”: der christliche Kaiser bei Ambro- 
Pośród zachowanych listów biskupa Ambrożego siedemnaście skierowanych jest do imperatorów. Odbiorcą największej ilości listów, bo jedenastu, jest cesarz Teodozjusz. Innymi adresatami listów biskupa Mediolanu są ówcześni władcy: Walentynian, Gracjan i Eugeniusz. Listy inspirowane były głównie różnymi wydarzeniami, które dotyczyły przede wszystkim wiary i Kościoła (np. listy 72. i 73. dotyczące prób odnowienia kultów pogańskich; list 75. w sprawie sporu o bazyliki), kwestii z pogranicza moralności i polityki (list 11. po masakrze w Tesalonice) i spraw natury rodzinno-państwowych (list 25. związany z pogrzebem cesarza Walentyniana), ale także stricte politycznych (list 30., w którym Ambroży zdaje relację cesarzowi Walentynianowi z poselstwa do Maksyma). Wszystkie one zawierają odniesienia do postawy, wzoru i wymagań wobec cesarza i w ten sposób prezentują one obraz chrześcijańskiego władcy.

Można powiedzieć, że streszczeniem idei chrześcijańskiego władcy w listach św. Ambrożego są słowa zaczerpnięte z listu 73.:

„Ty, bardzo chrześcijański cesarzu, masz okazać swą wiarę w prawdziwego

Boga, a także gorliwość w tej wierze, roztropność i pobożność"4.

Cesarz ma zatem okazywać wiarę, ma wierzyć w prawdziwego Boga, ma być gorliwy w wierze, ma być roztropny i pobożny. Wszystkie inne wskazówki zawarte $\mathrm{w}$ listach są tak naprawdę uzupełnieniem i dopełnieniem tej podstawowej „definicji” cesarza chrześcijańskiego, i zasadzają się przede wszystkim na tym, że władza cesarska pochodzi z ustanowienia Bożego, o czym Ambroży wielokrotnie przypomina władcom w swych listach. Cesarz Gracjan wybrany jest ,za boskim wyrokiem (divino electe iudicio)", Walentynianowi Bóg „,dał królestwo i mu je zachował”, ale również cesarstwo jest błogosławione i szczęśliwe, ponieważ Bóg „wybrał tak wielkiego władcę [Teodozjusza - M.W.] i ojca narodów"7. Boska opatrzność nie kończy się jednak tylko na wyborze cesarza, ale towarzyszy mu w pełnieniu jego misji. Bóg

sius und Johannes Chrysostomus, Stuttgart 1999; M. Sordi, I rapporti di Ambrogio con gli imperatori del suo tempo, w: „Nec timeo mori”. Atti del Congresso internazionale di studi ambrosiani nel XVI centenario della morte di sant'Ambrogio (Milano, 4-11 Aprile 1997), ed. L.F. Pizzolato M. Rizzi, Studia Patristica Mediolanensia 21, Milano 1998, 107-118. Ogólnie o listach Ambrożego skierowanych do Imperatorów i o relacji biskupa Mediolanu do cesarzy zob. R. Klein, Die Kaiserbriefe des Ambrosius. Zur Problematik ihrer Veröffentlichung, „Athenaeum” 58 (1980) 335-371.

${ }^{4}$ Ambrosius, Epistula 72, 3, ed. G. Banterle, SAEMO 21, Milano - Roma 1988, 38: „Ergo cum a te, imperator Christianissime, fides deo vero sit exhibenda, cum ipsius fidei studium cautio atque devotio", thum. P. Nowak: Święty Ambroży z Mediolanu, Listy, t. 3, BOK 28, Kraków 2012, 22.

${ }^{5}$ Tenże, Epistula 12 [extra coll.], 10, SAEMO 21, 246, BOK 28, 193.

${ }^{6}$ Tenże, Epistula 30, 3, ed. G. Banterle, SAEMO 19, Milano - Roma 1988, 290: „Omnipotentis dei, qui Valentiniano regnum, quod dederat, reservavi”, thum. P. Nowak: Święty Ambroży z Mediolanu. Listy, t. 1, BOK 9, Kraków 1997, 223.

${ }^{7}$ Tenże, Epistula 2 [extra coll.], 6, SAEMO 21, 192: „Vere dominus propitius est imperio Romano, quandoquidem talem principem et parentem principium elegit”, BOK 28, 151. 
jest Poręczycielem cesarskiego panowania (auctor imperii vestri) ${ }^{8}$, a pobożny cesarz może liczyć na wsparcie niebiańską pomocą

Skoro zaś cesarz wybrany jest przez Boga to musi być cesarzem chrześcijańskim, jak czytamy w przywołanej powyżej „definicji” idealnego władcy. Znajduje to również odzwierciedlenie w adresach listów przesyłanych do cesarzy, w których tytułuje ich jako: bardzo chrześcijańskich cesarzy (Christianissimo Imperatori) ${ }^{10}$, najbardziej chrześcijańskich władców (Christianissime principum ${ }^{11}$. Co ciekawe stosuje te wyrażenia jedynie w dwóch listach. Pierwszy tytuł stosuje jako swoiste captatio benevolentiae, gdyż list ten jest interwencją Ambrożego w sprawie próby przywrócenia kultów pogańskich w Cesarstwie Rzymskim i nazwanie cesarza „,bardzo chrześcijańskim” ustawia jasno kierunek, w którym powinien on zmierzać. Drugi tytuł ma najwyraźniej zabarwienie osobiste i emocjonalne. List 12., który otwiera ten adres, nie dotyczy konkretnej kwestii, lecz zawiera wyraźną pochwałę cesarza i jego wiary, co wzmocnione jest przez uwagę biskupa o przesłaniu imperatorowi dwóch dzieł teologicznych.

W kontekście władcy jako imperatora chrześcijańskiego Ambroży podkreśla w swych listach przede wszystkim dwie kwestie: walkę z herezjami i walkę z pogaństwem, które są wypełnieniem postulatu o wierze w prawdziwego Boga. W czasie pontyfikatu Ambrożego szczególnym zagrożeniem dla chrześcijaństwa był arianizm, który zdobył sobie wiernych wśród Longobardów, ale i na dworze cesarskim. Oczywiście zadaniem chrześcijańskiego cesarza jest popierać prawdziwą wiarę w prawdziwego Boga i dążyć do usunięcia arian. Dlatego też w liście z synodu w Akwilei do cesarzy Gracjana, Walentyniana i Teodozjusza, Ambroży w imieniu biskupów pisał z nadzieją, że choć w niektórych częściach cesarstwa zachodniego niektórzy sprzeciwiają się wierze, to jednak dzięki życzliwości cesarza, po ustaleniach synodu, uda się temu zaradzić $^{12}$. W liście zaś do cesarza Teodozjusza, również w imieniu biskupów Italii, chwali cesarza za dokonane już dzieła przywracania prawdziwej wiary:

„Wiedzieliśmy, że twój święty duch jest oddany wszechmogącemu Bogu przez czystą i szczerą wiarę, lecz przez niedawne dobrodziejstwa powiększyłeś to, czcigodny cesarzu, ponieważ przywróciłeś katolików do ich kościołów"13.

Cesarza Gracjana zaś chwali za to, że przywrócił spokój Kościoła i zamknął usta ludzi przewrotnych, czyli arian ${ }^{14}$. Ambroży nie nakazuje zatem wprost

\footnotetext{
${ }^{8}$ Tenże, Epistula 10 [extra coll.], 12, SAEMO 21, 230, BOK 28, 182.

${ }^{9}$ Por. tenże Epistula 2 [extra coll.], 1.

${ }^{10}$ Tenże, Epistula 72, 3, SAEMO 21, 38, BOK 28, 21.

${ }^{11}$ Tenże, Epistula 12 [extra coll.], SAEMO 21, 240, BOK 28, 173.

${ }^{12}$ Por. tenże, Epistula 6 [extra coll.], 3.

${ }^{13}$ Tenże, Epistula 9 [extra coll.], 1, SAEMO 21, 218: „Sanctum animum tuum deo omnipotenti pura et sincera fide deditum sciebamus, sed recentibus cumulasti beneficiis quod catholicos ecclesiis reddidisti, imperator auguste", BOK 28, 173.

${ }^{14}$ Por. tenże, Epistula 12 [extra coll.], 2. Na temat relacji Ambrożego do cesarza Gracjana zob.
} 
walki z herezja, ale raczej poprzez ukazanie dobrych czynów zachęca do czynienia kolejnych. Jednak jak się wydaje to nie przede wszystkim walka $z$ herezją stanowić ma - według biskupa Mediolanu - główne zadanie chrześcijańskiego cesarza, ale walka z pogaństwem. Wydaje się, że Ambroży uważa, że $\mathrm{w}$ walce $\mathrm{z}$ herezjami, $\mathrm{z}$ arianami, cesarz ma rolę pomocniczą, zaś walka z pogaństwem należy do jego głównych obowiązków. Świadczy o tym duża ilość wzmianek na ten temat w listach biskupa. W odpowiedzi na wypowiedź prefekta Symmacha, Ambroży wyraźnie wskazuje młodemu cesarzowi Teodozjuszowi jaką drogą ma podążać:

„Przez wiarę jesteś zobowiązany, byś nie szedł za przykładem pogańskiego obrzędu, a przez miłość rodzinną do tego, byś nie gwałcił postanowień twego brata" 15 .

Najpierw jednak ukazał cesarzowi obraz idealnego władcy chrześcijańskiego:

„Chrześcijański cesarz nauczył się otaczać czcią samego tylko Chrystusa. Czemu zmuszają pobożne ręce i wierne usta do spełniania służby przy ich świętokradztwach? Niech głos naszego cesarza wielbi Chrystusa i niech głosi Jego jednego, którego czuje, gdyż «serce króla» jest «w ręku» Boga (por. Prz $21,1)^{\prime \prime 16}$.

Ambroży wyraźnie przestrzega, że cesarz nie może nawet paktować z poganami na temat ewentualnego przywrócenia kultów pogańskich, nie może nawet odpowiadać na ich prośby, gdyż to grozi świętokradztwem ${ }^{17}$. Postępowanie zaś wbrew zaleceniom biskupa skutkować będzie oporem kapłanów ${ }^{18}$. Choć z drugiej strony Ambroży uwrażliwia cesarza na fałszywość nauki i słów pogan, zachęcając go jednocześnie do zbadania religii pogan, którzy:

„głoszą słowa wyszukane i wzniosłe, ale bronią rzeczy pozbawionych prawdy; mówią o Bogu, lecz adorują bożka"19.

J.-R. Palanque, Un épisode des rapports entre Gratien et saint Ambroise. À propos de la lettre I de saint Ambroise, REA 30 (1928) 291-301; G. Gottlieb, Ambrosius von Mailand und Kaiser Gratian, Hypomnemata. Untersuchungen zur Antike und zu ihrem Nachleben 40, Göttingen 1973; T.D. Barnes, Ambrose and Gratian, „Antiquité Tardive” 7 (1999) 165-174; Y.-M. Duval, Les Lettres d'Ambroise de Milan aux empereurs. Les échanges avec Gratien, w: Correspondances. Documents pour l'histoire de l'Antiquité tardive (Actes du colloque international, Lille, 20-22 novembre 2003), ed. R. Delmaire - J. Desmulliez - P.-L. Gatier, Collection de la Maison de l'Orient 40, Lyon 2009, 199-226.

${ }^{15}$ Ambrosius, Epistula 73, 39, SAEMO 21, 84: ,fidei tuae debeas, ut gentilicii ritus non sequaris exemplum, et pietati ut fratris statuta non violes", BOK 28, 54 .

${ }^{16}$ Tamże 73, 10, SAEMO 21, 68: „Christianus imperator aram solius Christi didicit honorare. Quid manus pias et ora fidelia ministerium suis cogunt sacrilegiis exhibere? Vox imperatoris nostri Christum resultet et illum solum quem sentit loquatur, quia «cor regis in manu dei»", BOK 28, 42.

${ }^{17}$ Por. tenże, Epistula 72, 12.

${ }_{18}^{18}$ Por. tamże 72, 13.

${ }^{19}$ Tenże, Epistula 73, 2, SAEMO 21, 62: „,[...] pretiosa et grandia sonant, veri effeta defendunt; deum loquuntur, simulacrum adorant", BOK 28, 39. 
Wydaje się, że - zgodnie ze słowami Ewangelii - chrześcijanie powinni zachowywać szczególną roztropność w kontaktach z innymi ludźmi. W listach Ambrożego odnajdujemy wiele wskazówek mówiących, w jaki sposób winien postępować władca chrześcijański. Przede wszystkim władca pełni swoją funkcję wobec poddanych, których powinien cierpliwie słuchać ${ }^{20}$. Ma szanować wolność wypowiadania się poddanych, gdyż jak twierdzi biskup Ambroży:

„Nie ma w was cesarzach, żadnej innej cechy tak cenionej przez lud i tak pociagającej jak uszanowanie wolności także w tych, którzy są wam poddani w posłuszeństwie [podobnym] jak w wojsku, gdyż ta jest różnica między dobrymi i złymi władcami, że dobrzy kochają wolność, a źli - niewolę"21.

Wobec kapłanów władca chrześcijański powinien okazywać szacunek, ponieważ oni pełnią służbę dla Boga ${ }^{22}$. Winien ich także słuchać w sprawach Bożych, przede wszystkim dlatego, że to kapłani mają odwagę mówić praw$\mathrm{dę}^{23}$. Oczywiście najwięcej miejsca poświęca Ambroży stosunkowi cesarza do biskupów, gdyż tym jest najbardziej osobiście zainteresowany. Biskup Mediolanu podkreśla przede wszystkim, że władca winien słuchać i radzić się biskupów. Jeżeli cesarz jest wierzący, jeżeli jest chrześcijaninem powinien iść za radą biskupa ${ }^{24}$, nawet pomimo tego, że nikt nie może zmusić cesarza do zrobienia czegokolwiek i nikt z ludzi nie ma nad nim władzy ${ }^{25}$. Cesarz powinien wspierać biskupów w tym wszystkim, co dotyczy wiary, a przede wszystkim w zachowaniu jedności Kościoła ${ }^{26}$. To współdziałanie ma się przejawiać w zwoływaniu synodów biskupich dla rozwiązania najważniejszych spraw kościelnych ${ }^{27}$, aby wiara nie poniosła szkody ${ }^{28}$. Ambroży w swych listach podnosi także kwestię relacji cesarza do biskupa Rzymu. Podkreśla przede wszystkim wyjątkową pozycję Następcy św. Piotra, zwracając uwagę cesarzowi, że ma on prawo bronić się przed radą cesarską albo przed soborem, a nie przed zwykłym sądem ${ }^{29}$. Zadaniem cesarza jest również bronić biskupa Rzymu i Kościoła w Rzymie - „Głowy całego rzymskiego świata (totius orbis Romani caput)" ${ }^{\prime 30}$ - zwłaszcza przed ludźmi, którzy chcą zniszczyć jedność Kościoła i którzy są heretykami.

${ }^{20}$ Por. tenże, Epistula 74, 4.

${ }^{21}$ Tamże 74, 2, SAEMO 21, 86: „Nihil enim in vobis imperatoribus tam populare et tam amabile est quam libertatem etiam in his diligere qui obsequio militiae vobis subditi sunt. Siquidem hoc interest inter bonos et malos principes quod boni libertatem amant, servitutem improbi”, BOK 28, 56.

${ }^{22}$ Por. tamże 74, 29.

${ }^{23}$ Por. tamże 74, 4.

${ }^{24}$ Por. tenże, Epistula 11 [extra coll.], 17.

${ }^{25}$ Por. tenże, Epistula 10 [extra coll.], 10.

${ }^{26}$ Por. tenże, Epistula 6 [extra coll.], 6.

${ }^{27}$ Por. tamże 6 [extra coll.], 5-6.

${ }^{28}$ Por. tenże, Epistula 74, 27.

${ }^{29}$ Por. tamże 7 [extra coll.], 11.

${ }^{30}$ Tenże, Epistula 5 [extra coll.], 4, SAEMO 21, 198, BOK 28, 157. 
Oczywiście Ambroży w swoich listach prezentuje całą paletę cech, którymi winien odznaczać się prawdziwy i idealny władca chrześcijański. Ma być pokor$n y^{31}$, i za pomocą pobożności - w której nieustannie ma wzrastać ${ }^{32}$ - powinien pokonywać swoją ułomną naturę ${ }^{33}$ i zwalczać pokusy ${ }^{34}$. Ma przebaczać, nawet tym, którzy zawinili ${ }^{35}$. Zamiast stawiać sobie pomniki i łuki triumfalne winien złożyć ofiarę Panu Bogu ${ }^{36}$. Powinien być przede wszystkim poddany Bogu ${ }^{37}$, a prawo, które stanowi nie może być ponad prawem Bożym ${ }^{38}$. Wszystko, co czyni powinno być pożyteczne dla jego zbawienia ${ }^{39}$. Ambroży podsumowuje te wszystkie cechy w jednym zdaniu skierowanym do cesarza Teodozjusza:

„Znam cię jako pobożnego, łaskawego, łagodnego i spokojnego; wiem, że leży ci na sercu wiara i bojaźń Pańska" ${ }^{40}$.

Gorliwość, roztropność w wierze i pobożność okazywało wielu cesarzy, którzy - według Ambrożego - powinni być przykładem dla ich następców. W kontekście wspólnej z biskupami troski o ortodoksję przywoływał on postać cesarza Konstantyna, który zachowywał wolność biskupów w sprawach należących do wiary i karności kościelnej, podobnie jak jego syn Konstancjusz ${ }^{41}$. On także wspomniany został przez Ambrożego jako wzór przeciwstawiania się pogaństwu ${ }^{42}$. Przedwcześnie zmarły Walentynian August posiadł według Ambrożego wielką pobożność, ukształtowaną przez cesarza Teodozjusza ${ }^{43}$. Wzorem powinni być jednak przede wszystkim najbliżsi. W liście 75. skierowanym do Walentyniana II szczególnie często przypomina właśnie jego ojca - Walentyniana I - i ukazuje go jako wzór postępowania i wiary dla następcy:

„[Jego] wiara została potwierdzona przez stanowczość w jej wyznawaniu i którego mądrość publicznie ogłaszają postępy w lepszej organizacji państwa" ${ }^{4}$.

Jednak Ambroży, znając ludzką słabość, także cesarską, jak o tym świadczą przykłady z relacji biskupa Mediolanu z władcami, zdawał sobie sprawę, że

${ }^{31}$ Por. tenże, Epistula 13 [extra coll.], 4.

${ }^{32}$ Por. tenże, Epistula 2 [extra coll.], 7.

${ }^{33}$ Por. tenże, Epistula 11 [extra coll.], 4.

${ }^{34}$ Por. tamże. 11 [extra coll.], 11.

${ }^{35}$ Por. tenże, Epistula 2 [extra coll.], 7.

${ }^{36}$ Por. tamże 2 [extra coll.], 4.

${ }^{37}$ Por. tenże, Epistula 10 [extra coll.], 8.

${ }^{38}$ Por. tenże, Epistula 75, 10.

${ }^{39}$ Por. tenże, Epistula 72, 17.

${ }^{40}$ Tenże, Epistula 74, 5, SAEMO 21, 88: „Novi te pium clementem mitem atque tranquillum, fidem ac timorem domini cordi habentem", BOK 28, 57.

${ }^{41}$ Por. tenże, Epistula 75, 15.

${ }^{42}$ Por. tenże, Epistula 73, 32.

${ }^{43}$ Por. tenże, Epistula 25, 2.

${ }^{44}$ Tenże, Epistula 75, 3, SAEMO 21, 108: „cuius et fides confessionis constantia comprobata est et sapientia melioratae rei publicae profectibus praedicatur", BOK 28, 72. Por. tamże 75, 2, 5. 
ludzkie wzorce i ludzkie wsparcie są niewystarczające i często błędne i dlatego pisał do cesarza Walentyniana:

„Ja też radzę ci uznawać zasługi sławnych mężów, lecz z pewnością przed wszystkimi Bogu należy przyznać pierwszeństwo"

Wydaje się, że kto tę zasadę spełnił, według Ambrożego zasługiwał przede wszystkim na miano chrześcijanina, czy też chrześcijańskiego cesarza, do czego zachęcał w swoich listach biskup Mediolanu.

Święty Ambroży z Mediolanu był pierwszym z wielkich biskupów zachodniej części Imperium, który żył i sprawował swój pontyfikat, gdy religia chrześcijańska stała się religio licita, a nawet przez krótki okres czasu mógł się on cieszyć ogłoszeniem chrześcijaństwa jako religio regalis. Stanowisko, które zajmował dawało mu możliwość, a nawet konieczność, częstych kontaktów z władcami Imperium. Zarówno więc osobiste doświadczenie władzy świeckiej, sprawowana funkcja, okoliczności społeczno-religijne, ale i racje duszpasterskie wpłynęły na to, że uformował on obraz chrześcijańskiego władcy, który starał się przekazywać swoim wiernym, ale przede wszystkim imperatorom, z którymi dzielił troskę o chrześcijański świat.

\section{AN IMAGE OF CHRISTIAN EMPEROR IN THE LETTERS OF ST. AMBROSE}

\section{(Summary)}

St. Ambrose of Milan was the first of the great bishops of the western part of the Empire, who lived and held his pontificate, when the Christian religion has become religio licita, and even for a short period of time he could enjoy the status of Christianity as religio regalis. The position which he held gave him an opportunity, or even necessity, frequent contacts with the rulers of the Empire. Therefore, both the personal experience of the secular power, the function exercised by him before he became a bishop, religious and social circumstances, but also pastoral reasons influenced the fact that he formed the image of a Christian emperor, that Ambrose tried to show to his flock, but most of all to the emperors with whom he shared his concern for the Christian world. The article shows the image of a Christian emperor in the letters of St. Ambrose.

Key words: Ambrose of Milan, letters, emperor, Christianity, faith.

Słowa kluczowe: Ambroży z Mediolanu, listy, cesarz, chrześcijaństwo, wiara.

${ }^{45}$ Tenże, Epistula 72, 6, SAEMO 21, 40: „Deferendum meritis clarorum virorum et ego suadeo, sed deum certum est omnibus praeferendum”, BOK 28, 23. 
